\title{
THE ROLE OF SENIOR PEERS IN STUDENTS' TRANSITION TO CLINICAL CLERKSHIPS
}

\author{
Dian Puspita Sari, Yoga Pamungkas Susani \\ Fakultas Kedokteran, Universitas Mataram, Mataram - INDONESIA
}

\section{ABSTRACT}

Background: Medical students' transition to clinical clerkship has been shown to be challenging. Students need to effectively adjust to the new learning environment. This study aims to explore the role of senior peers in students' experiences during transition to clinical clerkships.

Methods: A qualitative methodology was adopted for this study. Eight $4^{\text {th }}$ year medical students (5 female, 3 male) submitted audio diaries during their first 12 weeks of clinical clerkships. 73 audio diaries were collected in total. Data were analyzed thematically. Twenty-five out of the 73 audio diaries contained interactions with senior peer students and these interactions were captured in 38 excerpts. These excerpts were analyzed further to understand the role of senior peer students during the transition.

Results: Senior peer students helped to ease out transition to clinical clerkship by serving three roles: (1) transferring information on ways of working in a clinical environment, on social aspects of clinical environments and on learning issues; (2) providing exemplars in performing clinical tasks as well as learning tasks; (3) as co-workers who provided access and support students' participation.

Conclusions: Senior peer students in a clinical clerkship helped newcomers to navigate themselves in a clinical environment by helping them to build situational awareness, by supporting vicarious learning and supporting students' participation in a clinical environment.

Keywords: senior peers, transition, clinical clerkship, work-based learning

\section{PERAN REKAN MAHASISWA SENIOR DALAM TRANSISI MAHASISWA KE PENDIDIKAN KLINIK}

\section{ABSTRAK}

Latar belakang: Transisi mahasiswa kedokteran memasuki tahap pendidikan klinik merupakan masa yang penuh tantangan dan memerlukan penyesuaian. Penelitian ini bertujuan untuk menggali peran rekan mahasiswa senior dalam pengalaman mahasiswa menghadapi masa transisi ke pendidikan klinik

Metode: Penelitian ini menggunakan metode kualitatif. Delapan orang mahasiswa kedokteran tahun keempat mengumpulkan diari audio selama 12 minggu pertama mengikuti kepaniteraan klinik. Total diari audio yang terkumpul sebanyak 73 audio diari. Data dianalisis secara tematik. Duapuluh lima dari seluruh diari audio mengandung interaksi dengan rekan mahasiswa senior dan interaksi ini terekam dalam 38 petikan data yang dianalisis lebih jauh untuk memahami peran rekan mahasiswa senior selama masa transisi ke pendidikan klinik.

Hasil: Tiga peran utama rekan mahasiswa senior yang ditemukan dalam penelitian ini adalah (1) memberikan informasi mengenai cara kerja, lingkungan sosial dan pembelajaran, (2) memberikan contoh dalam kegiatan klinik dan pembelajaran, dan (3) sebagai rekan kerja yang ikut memberikan akses dan mendukung partisipasi mahasiswa dalam lingkungan klinik.

contact: dianps.md@gmail.com 
Kesimpulan: Keberadaan rekan mahasiswa senior di suatu kepaniteraan klinik berperan membantu navigasi mahasiswa ke dalam lingkungan pendidikan klinik dengan membangun pemahaman situasi mahasiswa akan lingkungan klinik, mendorong pembelajaran melalui vicarious learning serta mendukung mahasiswa berpartisipasi.

Kata kunci: rekan mahasiswa senior, transisi, pendidikan klinik, pembelajaran berbasis kerja

\section{PENDAHULUAN}

Dalam kontinum pendidikan kedokteran terdapat beberapa transisi, yaitu ketika seseorang memasuki tahap akademik di fakultas kedokteran, ketika mahasiswa yang telah menyelesaikan tahap akademik masuk ke tahap klinik, ketika lulusan dokter mulai memasuki dunia kerja. ${ }^{1}$ Transisi tidak semata-mata suatu momentum, tetapi melibatkan proses yang dinamis ketika seseorang berpindah dari satu kondisi ke kondisi lainnya. Proses transisi umumnya disertai perubahan yang besar, misalnya dalam hal tugas, tanggung jawab dan harapan yang memerlukan strategi penyesuaian diri agar dapat berfungsi penuh dalam lingkungan yang baru. ${ }^{2}$ Berbagai penelitian menunjukkan bahwa masa transisi mahasiswa kedokteran dari tahap akademik ke tahap klinik merupakan masa yang sulit, melibatkan beragam emosi dan meningkatkan stres yang dialami mahasiswa. ${ }^{2,3}$

Berbagai intervensi untuk mempermudah mahasiswa melalui masa transisi ini antara lain adalah dengan menyediakan sesi orientasi oleh staf ${ }^{4}$ dan menyiapkan buku panduan kepaniteraan. ${ }^{5}$ Selain intervensi oleh staf pengajar dan perencana kurikulum, ada pula intervensi yang melibatkan sesama mahasiswa untuk meneruskan informasi mengenai suatu kepaniteraan klinik yang telah dilalui pada mahasiswa lain yang akan mengikuti kepaniteraan tersebut. ${ }^{6}$ Akan tetapi, peneliti belum menemukan studi yang membahas manfaat atau pengaruh keberadaan rekan mahasiswa senior yang bersama-sama menjalani suatu stase kepaniteraan namun memulainya lebih awal. Di Fakultas Kedokteran Universitas Mataram, sistem seperti ini diterapkan pada sebagian besar stase kepaniteraan klinik.

Dalam artikel ini peneliti melaporkan hasil penelitian mengenai pengalaman mahasiswa fakultas kedokteran dalam menjalani transisi memasuki pendidikan tahap klinis dengan fokus pada peran rekan mahasiswa senior selama masa transisi.

\section{METODE}

Penelitian ini merupakan bagian dari payung penelitian yang mengeksplorasi pengalaman mahasiswa selama masa transisi ke pendidikan klinik, suatu penelitian kualitatif dengan pendekatan fenomenologi. Pendekatan fenomenologi adalah pendekatan kualitatif yang difokuskan pada menangkap pengalaman seseorang terkait suatu aktivitas atau konsep berdasarkan perspektif partisipan dan bagaimana individu memaknai fenomena sosial yang terjadi dalam kehidupannya sehari-hari. ${ }^{7}$ Pengalaman yang diteliti dalam studi ini adalah pengalaman partisipan menjalani proses pendidikan di tahap klinik pada 12 minggu pertama.

\section{Konteks}

Penelitian dilakukan pada mahasiswa Fakultas Kedokteran Universitas Mataram (FK UNRAM) yang telah menyelesaikan tahap Sarjana Kedokteran dan memasuki tahap pendidikan klinik pada tahun 2017. Mahasiswa dibagi ke dalam lima gerbong rotasi dengan jadwal yang sudah ditentukan. Pada sebagian besar stase kepaniteraan, gerbong mahasiswa yang baru memulai suatu stase akan bertemu dengan gerbong mahasiswa lain yang sudah menjalani stase yang sama beberapa minggu lebih awal. Kedua gerbong mahasiswa akan berada pada stase tersebut selama beberapa minggu sebelum akhirnya gerbong mahasiswa yang lebih dulu masuk menyelesaikan stasenya di bagian tersebut. Mahasiswa pada gerbong ini selanjutnya akan disebut sebagai 'rekan mahasiswa senior' dalam keseluruhan artikel ini. Sebelum memasuki tahap klinis, mahasiswa mendapatkan 
pengarahan mengenai sistem kepaniteraan klinik dan tata cara pengisian logbook atau catatan harian kepaniteraan di kampus dan materi orientasi dari bagian Pendidikan dan Pelatihan (Diklat) di RS pendidikan utama.

\section{Karakteristik peneliti}

Kedua peneliti merupakan dosen di institusi pendidikan tempat partisipan kuliah dan pernah terlibat mengajar dan menilai partisipan pada tahap akademik. Namun demikian kedua peneliti sama sekali tidak terlibat dalam proses pendidikan dan pelayanan di rumah sakit tempat partisipan menjalani pendidikan klinik sehingga tidak memiliki pengaruh langsung terhadap proses pendidikan dan penilaian partisipan. Kedua peneliti merupakan bagian dari Medical Education Unit di FK UNRAM yang antara lain berperan dalam pengembangan dan evaluasi kurikulum.

\section{Strategi sampling}

Penelitian ini menggunakan metode purposive sampling. Partisipan dipilih untuk mewakili setiap gerbong rotasi mahasiswa yang akan menjalani kepaniteraan pada bulan Maret 2017. Selain itu keterwakilan kedua jenis kelamin dan kemampuan partisipan dalam menceritakan pengalaman juga dijadikan dasar pertimbangan dalam memilih partisipan.

\section{Cara pengambilan data dan instrumen pengambilan data}

Partisipan diminta untuk menceritakan pengalaman mereka terkait proses pendidikan di tahap profesi dan direkam menggunakan alat perekam audio. Diari audio semacam ini memungkinkan partisipan menceritakan pengalamannya segera setelah kejadian sehingga mampu menangkap perubahan emosi yang menyertai pengalaman mereka. ${ }^{8}$

Sebagai stimulus awal dalam bercerita, partisipan diminta untuk menceritakan perasaannya mengenai pengalaman yang didapatkan pada hari itu ("Bagaimana perasaanmu hari ini?"), kemudian melanjutkannya dengan deskripsi pengalaman dan refleksi terhadap pengalaman tersebut. Partisipan diijinkan menceritakan apa saja yang mereka alami dalam kegiatan kepaniteraan klinik.

Untuk melindungi identitas partisipan, peneliti memberikan pseudonym untuk setiap partisipan yang disebutkan di awal rekaman audio. Terkait dengan kerahasiaan pihak-pihak yang terlibat dalam pengalaman yang diceritakan, partisipan diminta untuk menggunakan nama samaran.

\section{Isu etik}

Penelitian ini telah mendapatkan persetujuan etik dari komisi etik penelitian Fakultas Kedokteran Universitas Mataram. Setiap calon partisipan yang dikontak diberikan penjelasan mengenai penelitian ini sebelum dimintai kesediaan berpartisipasi. Keikutsertaan partisipan dalam penelitian ini bersifat sukarela dan partisipan dapat mengundurkan diri setiap saat tanpa ada konsekuensi apapun, baik materi maupun non-materi. Partisipasi dalam penelitian ini bersifat rahasia dan setiap partisipan diberikan pseudonym untuk menjaga identitas partisipan dalam data yang diambil. Selama 12 minggu periode pengumpulan data, peneliti beberapa kali mengingatkan partisipan untuk mengirimkan diari audio. Peneliti memberikan uang pengganti biaya pulsa internet yang digunakan dalam proses pengiriman data kepada peneliti dan souvenir ucapan terima kasih di akhir penelitian kepada seluruh partisipan yang berpartisipasi.

\section{Manajemen dan pengolahan data}

Untuk menjaga kerahasiaan data selama proses penelitian, peneliti memastikan semua data diari audio yang dikirim partisipan segera diunduh dan disimpan dengan identitas baru dalam folder khusus di komputer peneliti. Setelah disimpan, pesan yang diterima pada perangkat telepon seluler peneliti kemudian dihapus. Selanjutnya, diari audio ditranskripsi secara verbatim oleh pihak independen yang tidak berada ataupun bekerja di lingkungan institusi pendidikan tempat penelitian dilakukan.

Dalam menganalisis data, peneliti (DPS dan YPS) mulai dengan membaca keseluruhan data satu persatu dan berusaha untuk mendapatkan kesan umum, kesan mengenai kedalaman data, kredibilitas data, kegunaan informasi yang dikandung didalamnya, 
serta merefleksikan makna keseluruhan dari setiap data rekaman audio. Kesan awal yang didapatkan peneliti dicatat dan didiskusikan oleh DPS dan YPS. Berdasarkan pemahaman akan kesan yang didapatkan kedua peneliti mulai mengembangkan sistem kode awal untuk melakukan coding. Coding adalah proses mengorganisasi data dengan melabel potongan teks dalam data dengan sebuah kata atau lebih yang menggambarkan suatu kategori. Kata atau label yang digunakan dapat diambil dari katakata yang digunakan oleh partisipan. ${ }^{9}$ Sistem kode awal diujicobakan pada tiga transkrip untuk menilai kesesuaian aplikasi kode antara kedua peneliti. Perbedaan hasil coding didiskusikan antara kedua peneliti untuk menemukan solusi dan beberapa kode baru ditambahkan ke dalam sistem kode awal. Selanjutnya pengkodean sisa dokumen dilakukan oleh DPS dan YPS secara terpisah. Pemikiran yang muncul selama proses coding dicatat dalam memo.

Selain melabel data dengan kode dari sistem kode yang telah dikembangkan, setiap data juga diberikan deskriptor untuk menandai variabel karakteristik partisipan (kode identitas, jenis kelamin), dan variabel stase (bagian klinik dan sifat bagian klinik, tahapan stase serta lokasi stase). Bagian klinik dibagi menjadi bagian besar (Ilmu Penyakit Dalam, Ilmu Bedah, Ilmu Kesehatan Anak, Obstetri dan Ginekologi) dan bagian kecil (bagian-bagian lain selain keempat bagian tersebut). Tahapan stase dibagi menjadi 3: minggu awal, minggu pertengahan dan minggu akhir. Variabel terakhir yaitu lokasi stase dibagi menjadi RS pendidikan utama dan RS lainnya. Coding dan analisis data dilakukan menggunakan software penelitian mixed-methods Dedoose.

\section{HASIL DAN PEMBAHASAN}

Delapan dari sepuluh orang mahasiswa (5 perempuan, 3 laki-laki) yang diminta menjadi partisipan penelitian bersedia berpartisipasi dan mengirimkan diari audio. Sebanyak 73 diari audio yang menceritakan pengalaman sehari-hari mereka selama 12 minggu pertama mengikuti kepaniteraan klinik. Jumlah diari audio yang dikirimkan setiap partisipan bervariasi antara satu $1-24$ diari audio. Durasi diari audio bervariasi antara $1-25$ menit dengan total durasi 503 menit. Diari audio menceritakan pengalaman mahasiswa mengikuti sembilan bagian klinik (tabel 1). Sebagian besar diari audio menceritakan pengalaman kepaniteraan di bagian Ilmu Kesehatan Kulit dan Kelamin.

Tabel 1 Distribusi diari audio per bagian

\begin{tabular}{lc}
\multicolumn{1}{c}{ Bagian } & $\begin{array}{c}\text { Jumlah rekaman audio diari terkait } \\
\text { pengalaman di bagian }\end{array}$ \\
\hline Ilmu Kesehatan Kulit dan Kelamin & 31 \\
Anestesi dan Reanimasi & 15 \\
Neurologi & 8 \\
Ilmu Penyakit Dalam & 7 \\
Radiologi & 5 \\
Ilmu Kesehatan Jiwa & 4 \\
Ilmu Kesehatan Anak & 1 \\
Ilmu Bedah & 1 \\
Ilmu Kesehatan Mata & 1 \\
\hline Total & 73 \\
\hline
\end{tabular}


Duapuluh lima dari 73 rekaman audio diari mengandung petikan data mengenai interaksi dengan rekan mahasiswa senior. Total terdapat 38 petikan data yang memuat interaksi dengan rekan mahasiswa senior. Hampir seluruh petikan data (37) mengenai interaksi dengan rekan mahasiswa senior berasal dari pengalaman di minggu awal kepaniteraan klinik terutama pada minggu pertama (32 petikan data).
Dalam diari audio partisipan mengapresiasi peran dan keberadaan rekan mahasiswa senior dalam membantu mereka menyesuaikan diri dengan peran barunya sebagai mahasiswa di tahap pendidikan klinik. Secara umum terdapat tiga peran utama rekan mahasiswa senior yang ditemukan dalam pengalaman partisipan selama masa transisi: (1) memberikan informasi, (2) memberikan contoh dan (3) sebagai rekan kerja (tabel 2).

Tabel 2. Peran mahasiswa senior dalam masa transisi

Memberikan informasi

Cara kerja dan preferensi dosen klinis

Orientasi lingkungan

Memberikan contoh

Contoh kerja klinis

Rekan kerja
"Dan kakak - kakak senior itu untungnya juga mereka mengarahkan [...] kita juga boleh melakukan anamnesis terlebih dahulu baru [...] pasiennya ke ruangan untuk diperiksa lebih lanjut oleh dokternya. Namun ada juga katanya, dokter yang dokter pria yang lain, yang harus dimasukkan pasiennya tanpa dianamnesis oleh coass terlebih dahulu." (4M, stase Kulit hari ke-1)

"Enaknya di stase jiwa sekarang itu lagi ada senior, jadi tadi kita, saya sama beberapa temen saya tu uda dapet beberapa arahan dari senior, sebelum kita masuk dan juga saat masuk. Terus, jadi, dan juga enaknya tadi tu orientasi rumah sakit ga sendirian, jadi ditemenin sama senior. Dijelasin itu ruangan apa, dan bagaimana kondisi pasien yang ada disana." (5bF, stase Jiwa, hari ke-1)

"[...] jujur aja saya masih bingung, maksudnya, kalau nanti saya udah tiba disana, lalu misalnya mungkin menanyakan atau melihat di RM nya tentang diagnosis atau konsulan apa, dan melihat pasiennya, dan harus, harus menghubungi dokternya, itu masih bingung sih. Tapi untungnya tadi, berdua dengan kakak senior, jadi saya mengerti apa aja yang harus dilakukan, apa yang harus dicatat, dan disampaikan [...] seru sih, saya seneng banget, bisa liat langsung tadi gimana kakak seniornya yang melakukan sendiri pemeriksaan tadi dan menghubungi dokternya langsung." (4aF, stase Kulit hari ke-3)

"Tadi coba-coba juga sih untuk anamnesis, tapi masih dibantu-bantu juga sama kakak-kakak senior. Disini seneng banget sih sebenernya, kakak-kakak seniornya baikbaik banget, banyak banget ilmunya yang dishare ke kita. Jadi kitanya juga enggak sungkan buat nanya-nanya ke mereka, karena merekanya juga ga ngebatesin buat sharing, mereka juga enak banget buat sharing." (4aF, stase Kulit hari ke-6) 
Peran sebagai pemberi informasi yang ditemukan pada 15 diari audio partisipan terutama terjadi sebelum partisipan memulai suatu stase kepaniteraan hingga minggu pertama suatu stase. Informasi yang disampaikan mahasiswa senior berkaitan dengan cara kerja di lingkungan klinis seperti cara menulis data pasien dalam lembar status, tata cara pemeriksaan pasien pada setting pelayanan yang berbeda, sistem jaga, dan tatacara melaporkan pasien kepada konsulen. Aspek lingkungan sosial seperti norma tidak tertulis yang berlaku di suatu bagian, karakteristik dan preferensi dosen klinis baik dalam kegiatan kerja klinis ataupun penilaian serta karakteristik sekretaris bagian merupakan halhal yang umumnya diberitahukan pada dan dicari tahu oleh mahasiswa baru. Selain itu partisipan juga mendapatkan gambaran mengenai konten pembelajaran di suatu bagian dengan penekanan khusus pada hal - hal yang harus dikuasai. Rekan mahasiswa senior juga membagi tips mengenai cara belajar di suatu bagian.

Peran rekan mahasiswa sebagai pemberi informasi juga ditemukan dalam penelitian lain oleh Masters et $\mathrm{al}^{6}$ dan Chou et al. ${ }^{10}$ Sama seperti penelitian Masters et $a l,{ }^{6}$ rekan mahasiswa senior dalam penelitian ini memberikan akses pada informasi mengenai aspek budaya dalam lingkungan kerja, konten pembelajaran dan logistik yang diperlukan dalam menjalankan tugas klinik yang seringkali tidak disampaikan secara eksplisit dan cukup detil dalam orientasi awal. Informasi ini merupakan sumber daya relevan yang dapat memfasilitasi proses pembelajaran serta integrasi mahasiswa baru ke dalam tim pelayanan di lingkungan kerja klinik. Informasi ini juga memampukan mahasiswa baru untuk berkontribusi dalam kegiatan kerja klinik. ${ }^{10} \mathrm{Hal}$-hal yang diteruskan dari mahasiswa ke mahasiswa lain umumnya bersifat praktis dan mewakili aspek kurikulum informal dan kurikulum tersembunyi, yaitu sekumpulan aturan tidak tertulis yang harus dipahami oleh mahasiswa untuk bisa melalui suatu tahapan pendidikan., ${ }^{6,11}$ Meskipun dirasa sangat bermanfaat oleh partisipan, informasi yang didapat juga menimbulkan rasa takut dan cemas. Informasi seperti itu umumnya berkaitan dengan karakteristik orang-orang tertentu yang ditemui dalam pendidikan klinik yang berpotensi menimbulkan hambatan dalam proses pendidikan mereka, misalnya sikap dosen klinis dan sekretaris bagian. Kecemasan dalam berinteraksi dengan orangorang baru di lingkungan kerja klinis juga ditemukan dalam penelitian lain. ${ }^{12}$

Peran rekan senior yang lain adalah memberikan contoh. Peran ini ditemukan dalam 14 diari audio. Partisipan banyak belajar dengan mengamati rekan mahasiswa senior melakukan tugas klinis (contoh: anamnesis, pemeriksaan fisik dan penunjang), mempresentasikan tugas (presentasi kasus, tinjauan pustaka dan journal reading) dan menjalani proses penilaian (mini-CEX) terutama di minggu-minggu awal kepaniteraan. Dengan mengamati bagaimana mahasiswa senior mengerjakan berbagai tugas ini dan mempelajari umpan balik dari dosen klinis, partisipan belajar memahami hal-hal yang dianggap penting dalam kerja klinis, penugasan maupun penilaian. Hal ini menunjukkan peranan pembelajaran melalui pengamatan (vicarious learning) dalam masa transisi. Meskipun pembelajaran paling kuat terjadi melalui pengalaman terlibat secara langsung, namun pembelajaran dapat juga terjadi melalui pengamatan terhadap perilaku orang lain dan konsekuensi dari perilaku tersebut. ${ }^{13,14}$ Kurangnya pengalaman yang cukup untuk mendasari persepsi pembelajar meningkatkan manfaat vicarious learning ketika seseorang memasuki lingkungan yang baru..$^{14,15}$ Disamping membantu mempercepat terbentuknya pemahaman, belajar melalui pengamatan terhadap orang lain dapat meningkatkan efikasi $\operatorname{diri}^{15}$ terlebih ketika orang tersebut berada pada level pembelajaran yang sama seperti sesama mahasiswa. Hal ini didukung oleh penelitian oleh Lockpeiser et al. ${ }^{16}$ mengenai peran rekan mahasiswa senior pada pendidikan kedokteran di tahap akademik yang menunjukkan bahwa near peers dapat menjadi role model dan membangun kepercayaan diri mahasiswa junior dalam mengatasi kecemasan yang timbul akan suasana pembelajaran yang baru.

Peran ketiga sebagai rekan kerja ditemukan pada sembilan audio diari. Keberadaan mahasiswa senior sebagai rekan kerja membantu partisipan untuk terlibat dan berpartisipasi dalam kegiatan kerja klinis, terutama dalam kondisi absennya undangan dari dosen klinis untuk terlibat. Partisipasi merupakan 
bagian penting dari lingkungan pendidikan klinik dan perkembangan mahasiswa dapat diakselerasi dengan menciptakan kondisi yang memungkinkan mahasiswa untuk berpartisipasi pada level yang lebih tinggi. ${ }^{17}$ Untuk dapat terlibat dan berpartisipasi, mahasiswa baru perlu diundang oleh orang dalam lingkungan klinik, misalnya dosen. ${ }^{12}$ Partisipan dalam penelitian ini merasa canggung untuk menunjukkan inisiatifnya pada dosen klinis sehingga tanpa adanya ajakan dan kesediaan mahasiswa senior untuk melakukan tugas bersama-sama, partisipasi mereka menjadi terhambat. Hasil penelitian ini menemukan bahwa rekan mahasiswa senior mampu menawarkan dukungan sosial dan afektif yang membuat partisipan merasa aman untuk berpartisipasi. Hal ini dimungkinkan oleh adanya kongruensi sosial di antara sesama mahasiswa yang memungkinkan mahasiswa untuk lebih terbuka dalam menunjukkan ketidaktahuannya. ${ }^{11}$ Selain itu, pemahaman rekan mahasiswa senior mengenai aturan yang berlaku di lingkungan klinik juga memungkinkan mereka untuk membantu mahasiswa baru berpartisipasi dalam kegiatan klinik.

Pada beberapa kondisi keberadaan mahasiswa senior juga dapat menghambat interaksi dan partisipasi dalam lingkungan klinis, yaitu ketika kesempatan untuk mengerjakan tugas-tugas bermakna ataupun kesempatan untuk mempelajari kasus terbatas. Umumnya mahasiswa senior memiliki peluang lebih besar untuk terlibat dalam kesempatan yang terbatas. Meskipun keberadaan rekan mahasiswa senior berpotensi menciptakan hirarki pembelajar ${ }^{18}$ dan mempengaruhi kesempatan partisipan untuk mendapatkan pengalaman langsung dalam pelayanan pasien, namun tidak tampak adanya persaingan antara partisipan dengan mahasiswa senior dalam penelitian ini. Justru sebaliknya, partisipan menunjukkan kesediaan mengalah dan membiarkan rekan mahasiswa senior lebih dulu mendapatkan kasus lebih dahulu untuk keperluan penilaian mereka. Hal ini mungkin menggambarkan kekhasan budaya di lokasi penelitian yang berbeda dengan tempat lain. Penelitian oleh Lempp \& Seale ${ }^{19}$ di Inggris misalnya, menunjukkan bahwa suasana kompetisi pada tahap pendidikan klinik lebih kuat dibandingkan tahap akademik dan mahasiswa pada tahap klinik berusaha keras untuk membuat dosen terkesan untuk mendapatkan promosi dalam karir mereka di masa depan. Persaingan antar mahasiswa di tahap klinik juga diidentifikasi dalam penelitian Chou et $\mathrm{a}^{10}$ mengenai pembelajaran berbasis lingkungan kerja melalui sesama mahasiswa di lingkungan kerja klinis.

Keberhasilan pembelajaran berbasis kerja (workplace based learning) dalam pendidikan klinik ditentukan oleh hubungan saling terkait antara kualitas lingkungan belajar klinik yang memberikan kesempatan untuk berpartisipasi dengan keterlibatan individu mahasiswa. Lingkungan belajar klinik dibangun melalui interaksi antara komunitas dalam lingkungan kerja dengan mahasiswa. Mahasiswa yang baru masuk merupakan anggota perifer dari komunitas lingkungan kerja klinik yang sedang berusaha untuk mengonstruksi pemahaman tentang lingkungan kerjanya dan menjadi bagian dari pemegang peran mulai peran marjinal menuju peran sentral. Tidak ada petunjuk atau "peta" eksplisit bagi mahasiswa baru untuk menjalani proses tersebut. ${ }^{20}$ Kehadiran mahasiswa senior di suatu bagian klinik dapat berperan sebagai "sketsa peta" yang secara tidak tertulis memberikan gambaran arah atau petunjuk bagi mahasiswa baru untuk berproses dan berpartisipasi di dalam lingkungan kerja klinik.

\section{Limitasi}

Beberapa keterbatasan dalam penelitian ini antara lain adalah jumlah partisipan yang kecil, partisipan hanya berasal dari satu institusi dan sebagian besar diari audio yang terkumpul merupakan pengalaman partisipan di dua bagian klinis dengan durasi singkat (5 minggu). Namun demikian, peran rekan mahasiswa senior yang ditemukan dalam penelitian ini sesuai dengan penelitian-penelitian lain, ${ }^{6,10}$ sehingga dapat dikatakan cukup representatif untuk menggambarkan peran rekan mahasiswa senior dalam masa transisi ke pendidikan klinik. Studi ini membuka beberapa peluang penelitian lanjutan yaitu penelitian untuk membandingkan partisipasi mahasiswa selama masa transisi pada sistem kepaniteraan klinik dengan dan tanpa keberadaan mahasiswa senior. 


\section{KESIMPULAN}

Penelitian ini memberikan wawasan mengenai berbagai peran rekan mahasiswa senior dalam masa transisi partisipan memasuki tahap pendidikan klinik. Melalui penelitian ini, diketahui bahwa keberadaan rekan sesama mahasiswa yang lebih dulu mengikuti suatu kepaniteraan klinik dapat membantu proses adaptasi dan sosialisasi mahasiswa ke lingkungan pendidikan klinik serta mendukung partisipasi mahasiswa dalam kegiatan pembelajaran klinis. Keberadaan rekan mahasiswa senior dapat membantu membangun pemahaman situasi mahasiswa akan lingkungan kerja klinis di stase kepaniteraan yang diikutinya, mendorong pembelajaran melalui vicarious learning serta mempermudah akses mahasiswa untuk berpartisipasi dalam kegiatan klinis di minggu-minggu awal.

\section{DAFTAR PUSTAKA}

1. Susani YP, Rahayu GR, Sanusi R, Prabandari YS, Mardiwiyoto H. Model Identitas Profesional Mahasiswa Kedokteran. Universitas Gadjah Mada; 2015.

2. Teunissen PW, Westerman M. Opportunity or threat: The ambiguity of the consequences of transitions in medical education. Med Educ. 2011;45(1):51-9.

3. Godefrooij MB, Diemers AD, Scherpbier AJJA. Students'perceptions about the transition to the clinical phase of a medical curriculum with preclinical patient contact; a focus group study. BMC Med Educ. 2010;10(28):1-9.

4. Moineau G, Bannister S. Clinical placements: setting the stage. Clin Teach [Internet]. 2006;3(1):39-42. Available from: http://onlinelibrary.wiley.com/ doi/10.1111/j.1743-498X.2006.00071.x/full

5. Atherley A, Taylor C. Student perceptions of clerkship handbooks. Clin Teach. 2017;14(4):242-6.

6. Masters DE, O'Brien BC, Chou CL. The third-year medical student grapevine: Managing transitions between third-year clerkships using peer-to-peer handoffs. Acad Med. 2013;88(10):1534-8.

7. Gay L, Mills G, Airasian P. Educational research: Competencies for analysis and applications. 10th ed. Boston: Pearson; 2012. 672 p.

8. Brennan N, Corrigan O, Allard J, Archer J, Barnes R, Bleakley A, et al. The transition from medical student to junior doctor: Today's experiences of Tomorrow's Doctors. Med Educ. 2010;44(5):449-58.
9. Creswell JW. Research Design: Qualitative, Quantitative and Mixed Methods Approaches. 4th ed. Los Angeles: Sage; 2014. 1-361 p.

10. Chou CL, Teherani A, Masters DE, Vener M, Wamsley M, Poncelet A. Workplace learning through peer groups in medical school clerkships. Med Educ Online. 2014;19(1).

11. Ten Cate $O$, Durning S. Dimensions and psychology of peer teaching in medical education. Med Teach [Internet]. 2007;29(6):546-52. Available from: http://www.tandfonline.com/doi/ full/10.1080/01421590701583816

12. Hägg-Martinell A, Hult H, Henriksson P, Kiessling A. Medical students' opportunities to participate and learn from activities at an internal medicine ward: an ethnographic study. BMJ Open [Internet]. 2017;7(2):e013046. Available from: http://bmjopen. bmj.com/lookup/doi/10.1136/bmjopen-2016013046\%5Cnhttp://www.ncbi.nlm.nih.gov/ pubmed/28196948

13. Bandura A. Social foundations of thought and action: A social cognitive theory. Social foundations of thought and action: A social cognitive theory. Englewood Cliffs, NJ, US: Prentice-Hall, Inc; 1986. xiii, 617-xiii, 617. (Prentice-Hall series in social learning theory.).

14. Kaufman DM, Mann K. Teaching and learning in medical education: How theory can inform practice. In: Swanwick T, editor. Understanding Medical Education: Evidence Theory and Practice. 2nd ed. West Sussex: ASME, Wiley Blackwell; 2014. p. 7-28.

15. Bandura A. Self-Efficacy: The Exercise of Control. New York: WH Freeman; 1997.

16. Lockspeiser TM, O'Sullivan P, Teherani A, Muller J. Understanding the experience of being taught by peers: the value of social and cognitive congruence. Adv Health Sci Educ Theory Pract. 2008 Aug;13(3):361-72.

17. Dornan T, Scherpbier A, Boshuizen H. Supporting medical students' workplace learning: experiencebased learning (ExBL). Clin Teach. 2009;6:167-71.

18. Sheehan D, Wilkinson TJ, Bowie E. Becoming a practitioner: Workplace learning during the junior doctor's first year. Med Teach. 2012;34(11):936-45.

19. Lempp H, Seale C. The hidden curriculum in undergraduate medical education: qualitative study of medical students' perceptions of teaching. BMJ. 2004 Oct;329(7469):770-3. 
20. Liljedahl M, Björck E, Ponzer S, Bolander Laksov K. Navigating without a map: how medical students interact with clinical learning environments. Stud
High Educ [Internet]. 2017 Aug 8;1-12. Available from: https://www.tandfonline.com/doi/full/10.10 $80 / 03075079.2017 .1359822$ 